\title{
FOTOGRAFÍA: VIAJE, COLECCIONISMO Y EDUCACIÓN. LA HISPANIC SOCIETY OF AMERICA, SU FONDO FOTOGRÁFICO Y MURCIA ${ }^{1}$
}

\author{
José Fernando Vázquez Casillas* \\ Universidad de Murcia \\ https: //orcid. org/0000-0001-9443-4982
}

\section{RESUMEN}

Este estudio analiza la importante conexión existente entre conceptos como el viaje, el coleccionismo y la educación en la construcción del archivo fotográfico de la Hispanic Society of América; al tiempo que pone en valor los documentos gráficos que sobre la región de Murcia posee. Unas obras, estas últimas, que son fruto directo tanto de los fotógrafos viajeros que transitaron por nuestro país desde la segunda mitad del siglo XIX, en su vertiente de turista romántico o profesional, como de las expediciones a España, culturales y formativas, organizadas por la propia institución para sus conservadoras, bibliotecarias y fotógrafas, a principios del XX.

Palabras clave: Fotografía; viaje; coleccionismo; educación.

\section{Photography: travel, collecting and education. The Hispanic Society of America, its photographic collection and Murcia}

\begin{abstract}
This study analyzes the important connection between concepts such as travel, collecting and education in the construction of the photographic archive of the Hispanic Society of America and, at the same time, itputs in value the graphic documents that this institution keep about the region of Murcia (Spain). These works are the direct result not only of documental vision
\end{abstract}

Fecha de recepción: 31 de enero de 2019.

Fecha de aceptación: 24 de julio de 2019.

* Departamento de Historia del Arte. Universidad de Murcia. Campus de La Merced. 30001 MURCIA (España).E-mail: casillas@um.es

1 Mis agradecimientos al Dr. Patrick Lenaghan, Conservador de Grabados y Fotografías, y a la Dra. Noemí Espinosa, Conservadora adjunta de Grabados y Fotografías, de la Hispanic Society of America, por la ayuda prestada para el desarrollo de esta investigación. 
of the traveling photographers who visited our country since the second half of the 19th century but also of the cultural and formative expeditions to Spain, organized by the institution it self directed to its curators, librarians and photographers, at the beginning of the twentieth.

Keywords: photography; trip; collecting; education.

\section{ARCHER MILTON HUNTINGTON, LA HISPANIC SOCIETY OF AMERICA Y LA FORMACIÓN DE SU COLECCIÓN FOTOGRÁFICA}

La fotografía aplicada a la documentación del mundo, en esa búsqueda de un conocimiento universal, es un asunto intrínseco a su propio desarrollo. Desde el daguerrotipo, primera versión comercial del procedimiento fotográfico, su quehacer se va a aplicar (e implicar) en un proceso de catalogación visual coleccionable de todos los rincones del planeta, cumpliendo los anhelos y deseos de una nueva sociedad que demanda ahora un consumo particular (y posesión) de la cultura. Su peculiar naturaleza (mecánico-química) la caracteriza como la herramienta ideal para transcribir con realismo (y verdad) la contemporaneidad de su tiempo. Una singularidad que la convierte en un utensilio valiosísimo, tanto para registrar objetiva y subjetivamente el viaje individual y colectivo, como para generar un producto económico y, por ende, democrático, que aliente al común de la sociedad al coleccionismo de imágenes; al tiempo de ser a la vez una fuente precisa y trascendental para la educación, e investigación, en las diferentes ramas del conocimiento, como son la científica, la política, la cultural o la antropológica. Se trata, por lo tanto, de un dispositivo que se aplica a tres factores fundamentales que caracterizan a la colectividad de finales del siglo XIX y principios del XX; es decir, a tres campos de actuación concretos y relacionados que tienen como punto de unión al procedimiento fotográfico, y es que el viaje, el coleccionismo y la educación (antropológico-cultural) se activan y desarrollan, precipitadamente, con la propia evolución de este procedimiento técnico expresivo, siendo en este caso un ejemplo paradigmático, de esta teoría y tesis, el fondo fotográfico acumulado por Archer Milton Huntington para su institución Hispanic Society of America. Un viajero, investigador y coleccionista, anómalo -con respecto al tiempo que le tocó vivir-, que como principio efectivo plantea documentar fotográficamente España, para capturar así todos los aspectos socioculturales de un pueblo que camina hacia el abandono de sus vestigios del pasado.

Para comprender todo este programa se debe tener en cuenta que Huntington es una figura clave para la extensión y conocimiento de la cultura española en Norteamérica, presentándose como uno de los grandes coleccionistas de arte y filántropos de los Estados Unidos; y esto se hace evidente cuando se contempla el imponente muestrario de arte español de la Hispanic Society, compilación que no tiene parecido, en calidad y alcance, con ninguna otra fuera de España; a lo que hay que añadir, en su valoración, que fue erigida y consolidada por un único estudioso. Estamos, por lo tanto, ante un investigador que va a congregar, con un interés altruista, entre 1890 y 1920, una de las grandes colecciones de arte español del mundo (Codding, 2017: 21). 
Por lo expuesto es evidente que se trata de un hombre con una gran formación intelectual. Un individuo que hace del viaje un método formativo desde su juventud, recorriendo Europa interesándose por la cultura de los territorios visitados; y es en una de esas intensas travesías, concretamente durante su estancia en Londres, en 1882 (Lenaghan, 2012: 17), cuando adquiere el libro The Zincali de George Borrow (Borrow, 1841). Un manuscrito que marca un punto de inflexión en su búsqueda, pues es este estudio el que despierta en él su interés y pasión por la cultura española (Lenaghan, 2014: 162). De este modo, a partir de 1892, realiza diferentes visitas a la península, que conforman en Huntington una imagen precisa de España; una imagen conceptualizada que va a ser crucial para componer, mental y físicamente, su modelo de museo ideal (Lenaghan, 2014: 163); esto es, un espacio reflexionado en el que albergar ejemplos representativos de los principales periodos, escuelas y autores del arte español (Codding, 2017: 22).

Pese a todo este contexto hay que aclarar que Huntington no es un coleccionista corriente que ejerce tal rol como un pasatiempo o un divertimento social; por el contrario, lo practica como una ocupación vital, como un modo consciente de vida, teniendo desde el primer instante, como sueño de idea altruista, el objetivo de fundar un museo hispánico que se convierta con el tiempo en un legado significativo de arte español para sus conciudadanos (ibid. : 21). Y es que cuando Huntington funda la Hispanic Society está efectuando una acción paralela a otros coleccionistas contemporáneos a él -es a priori una actitud global-; es decir, que su intención primaria es comparable a la de diferentes agentes sociales que también están cumpliendo su labor altruista, o lo harán en breve, formando fondos o recopilaciones artísticas en pro de su imagen personal y de la salvaguarda y expansión del conocimiento (Jiménez Blanco y Mack, 2010); por lo tanto se suma a una corriente general protagonizada por seres sobresalientes en Norteamérica. Sin embargo, Huntington supone una excepcionalidad; y esto es así porque, por un lado, rechaza cualquier síntoma de fama personal. Y porque, por otro, concibe el fondo con una ideología que discrepa, totalmente, del resto de fundaciones de su época, ya que Huntington plantea su museo con la singularidad, como apunta Patrick Lenaghan, de ser encarnado con una visión enciclopédica de España -en todos los aspectos de su cultura (Lenaghan, 2017a: 62)-. Por lo expuesto, queda claro que la Hispanic representa de forma física, con evidencia, las propias ilusiones de su creador; unos sueños que nunca traiciona, siendo ejecutados sin buscar en ningún caso, como ya se ha apuntado, su particular fama. Asunto que bien atestigua el hecho de que ninguna de sus obras ostente su propio nombre.

Todos estos pensamientos quedan claramente explicados cuando apunta, a propósito de cómo desea que sea su centro: [...] Un museo que ha de abarcar las artes, incluyendo las artes decorativas, y las letras, ha de condensar el alma de España en contenidos a través de la mano y del espíritu. No ha de ser un montón de objetos acumulados al buen tuntún hasta que todo ello parezca una asamblea artística, los vestigios medio muertos de naciones entregadas a una orgía. Lo que quiero es ofrecer el compendio de una raza [...] (Lenaghan, 2012: 19).

Así, y tras un periplo de recopilación de material artístico, el 18 de marzo de 1904 se funda en la ciudad de Nueva York la Hispanic Society of America², siendo concebida

2 En ese momento es todavía una joven colección de tan solo veintitrés pinturas (Codding, 2017: 30). 
por el gran coleccionista Archer Milton Huntington como una biblioteca, un museo y, por supuesto, como institución educativa pública y gratuita (Lenaghan, 2009b: 213); la cual va a abrir sus puertas al visitante (e investigador) en el año 1908, celebrándose al año siguiente, como ejemplo de su política, una importante exposición del pintor Joaquín Sorolla (Lenaghan, 2007b: 66) ${ }^{3}$-un hecho que va a marcar, sintomáticamente, la construcción del archivo fotográfico-. Como se puede apreciar en su propia base ideológica, hablamos de un organismo que desde su inicial desarrollo se propone ser un centro dinámico, moderno y vivo, en el que los estudiosos encuentren un espacio para iniciar y extender sus conocimientos de una cultura concreta, siempre mediante una experiencia vital a través del contacto directo con objetos artísticos, históricos y literarios, de diferentes periodos cronológicos. Se trata, por lo tanto, con seguridad, de un empeño personal del propio fundador de ofrecer a todo interesado la posibilidad de conocer, estudiar y comprender (en profundidad) una cultura, en este caso la española (Lenaghan, 2014: 161) -lo que viene a ejemplificar uno de los capítulos esenciales de la difusión de nuestra historia-. Luego, plantea la fundación como un espacio en el que estudiar la cultura española desde todas las perspectivas posibles, convirtiéndose esta, con el tiempo, en el canal más importante para desarrollar y propagar, a través de sus publicaciones, las más significativas investigaciones de los hispanistas en general (Codding, 2017: 22).

En todo este contexto global, la fotografía como documento y fuente imprescindible de conocimiento, desde finales del siglo XIX, va desempeñar un papel culminante. El afán de Huntington por divulgar la cultura española le lleva a diseñar un plan integral estratégico con el que poder descodificar y entender todo el patrimonio depositado en su museo. Este plan contempla, desde el primer momento como veremos, la creación de un fondo documental fotográfico que, dada su naturaleza, se convierte en una herramienta eficaz para el investigador. En este sentido, este coleccionista, como hombre moderno de su tiempo, es consciente del importante rol que puede desempeñar el procedimiento fotográfico como instrumento de apoyo a los diferentes estudios que pudieran generarse (Lenaghan, 2012: 19) -no hay que olvidar que la fotografía, como fuente, va a ser y es trascendental para la comprensión de la historia contemporánea-. Así pues, para que su proyecto quede completo, Huntington determina que su institución tiene que poseer un considerable archivo fotográfico, el cual debe albergar distintas temáticas relacionadas con las costumbres españolas y, por supuesto, sobre su arte (Lenaghan, 2007a: 60); o sea, una colección que va a reunir imágenes de manifestaciones artísticas pero también una profunda documentación de aspectos etnográficos, registrando vestidos, oficios y tradiciones locales (Lenaghan, 2014: 166). En este sentido, debe tenerse en cuenta que para Huntington etnografía y arqueología comparten un mismo trabajo de campo, aunque diferente metodología (Lenaghan, 2009b: 216), por lo que no tiene ningún inconveniente en posicionarlos en un mismo nivel jerárquico.

Como consecuencia de lo expuesto es indudable que la creación de este específico archivo fotográfico le va a dar la posibilidad a Huntington de dejar, como ya había realizado en su colección artística y bibliográfica, su propia impronta. Evidentemente, todo

3 Como derivación de la misma, en 1911, recibe de la institución el encargo de realizar una serie de lienzos de gran formato, teniendo como temática la representación de la esencia de las tradiciones y trajes típicos de distintas regiones de España (Codding, 2017: 33). 
él sigue un programa orquestado por el coleccionista, que va a tener como derivación, aun estando compuesto por piezas de distintos autores, el presentar una unidad temáticoconceptual, abordando en su construcción siempre una búsqueda de calidad y nitidez (Espinosa Fernández, 2018: 15). El conjunto se compone de 176. 000 imágenes, aproximadamente, las cuales (en la mayoría de los casos) están desarrolladas bajo el procedimiento técnico del blanco y negro, aunque también se localizan procesos en color y otros materiales como postales impresas. Se trata de un fondo organizado que queda dividido en dos partes: la primera de ellas atiende a imágenes de obras de arte tanto de España como de Latinoamérica ${ }^{4}$; mientras que la segunda contiene instantáneas que documentan la vida y costumbres de ambos territorios; eso sí, dirigiendo su mirada a los espacios alejados de las grandes capitales (Lenaghan, 2007b: 64), y dando protagonismo en su clasificación interna a cuestiones geográficas (en el caso de España, se organiza según las divisiones políticas existentes en los años veinte) (ibid.: 69).

Una de las razones por las que el archivo fotográfico pone su interés, concretamente, en los aspectos ya citados de la cultura española, viene determinada porque el propio Huntington considera que la verdadera y auténtica España se encuentra fuera de los núcleos urbanos de las grandes ciudades (Lenaghan, 2017a: 63); es decir, que siente una auténtica atracción -idealizada- por las regiones rurales que visita, en sus estancias, alejadas de las grandes metrópolis. Son, según su propio pensamiento, imágenes genuinas, correctas, lejanas de las percepciones que manifiestan los turistas al uso (los románticos), aquellos que tan solo examinan el país en busca de tópicos (Lenaghan, 2014: 163). Y es que este intelectual apunta, reflexivamente, que estos territorios, los apartados, habían eludido el contacto directo con el mundo moderno e industrializado, permaneciendo así fieles a los valores tradicionales (Lenaghan, 2017a: 63). Un asunto que queda patente cuando desarrolla y publica su estudio A Note-bookin Northern Spain (Huntington, 1898); publicación que transcribe directamente sus experiencias, aquellas que interioriza adentrándose donde fuera necesario, por muy remoto que fuera el lugar, para saciar su interés y búsqueda -determinación que le llevó a profundizar en la España desconocida (Lenaghan, 2009b: 215)-. Hay que tener en cuenta que para Huntington cada localidad que compone el territorio español tiene una particularidad especial, esa que le otorga su propio carácter, esa que queda reflejada en sus tradiciones, en sus costumbres o simplemente en sus vestimentas (Lenaghan, 2012: 19). Tan profunda es esta noción para él que, cuando sus conservadoras y fotógrafas realicen trabajos documentales en España, les va a imponer la regla de no interesarse, por ejemplo, por las industrias modernas o por el amplio sistema del ferrocarril (Espinosa Fernández, 2018: 17) -incluso va a marcar el repertorio visual que tienen que proyectar estas imágenes y sus características narrativas (Lenaghan, 2009a: 35-36)-. Y es que este erudito coleccionista entiende la cultura en su diversidad, dándole un valor significativo a las tradiciones regionales; un aspecto señalado en todo este acervo, pues le ayuda y capacita para tener una visión globalizada e integral (subjetiva) de la particularidad identitaria de esta nación. Además, no se debe pasar por alto que cuando Huntington ensalza los valores culturales de zonas rurales que forman parte de ese carácter nacional en su amplitud, su actitud y posicionamiento lo asemejan a los del escritor y filósofo español

4 Sobre las imágenes de Latinoamérica puede verse: (Lenaghan, 2017b) y (Lenaghan, 2018b). 
Miguel de Unamuno (Lenaghan, 2017a: 65), quien asienta el valor de la intrahistoria, de la tradición y de lo eterno (Escobar Borrego, 2003). Todo este contexto se debe tener presente para comprender la colección bibliográfica y artística en general y la fotográfica en particular de la Hispanic, pues esa definición amplia de la cultura hace posible igualmente que la elección de las obras lo sea también, abarcando entonces pintura, escultura y las artes decorativas, y exponiendo desde el principio la necesidad de poseer una colección exhaustiva de fotografías para el conocimiento de todo ello (Lenaghan, 2017a: 65).

Huntington ya coleccionaba fotografías antes incluso de la creación de la Hispanic; algunas de ellas las había realizado él mismo y otras las había comprado; en cualquiera de los casos siempre buscaba una historia narrada a través de la claridad de sus escenas. Por lo tanto es evidente que las imágenes que él mismo efectuó o adquirió son el punto de partida para la creación del mencionado fondo de fotografía, al tiempo que son también ejemplo o canon a seguir dentro de la propia colección (Lenaghan, 2007a: 57). En este sentido, él mismo apunta: [...] Las fotografías constituyen una especie de diario y tengo un cuaderno de notas sobre ellas. Llega uno a darse cuenta de lo mucho que se puede aprender de ellas, y conservan los detalles que nuestra memoria no es capaz de guardar [...] (ibid. : 61)

La valoración que de las mismas hace, como detalla Noemí Espinosa en su tesis doctoral, demuestra una clara intención por parte de Huntington de usar la fotografía como una herramienta tecnológica aplicada al conocimiento y al estudio (Espinosa Fernández, 2010: 133). Así pues, todo este patrimonio documental viene determinado por esa necesidad de ser fuente directa para la comprensión de la cultura y tradición de un país. De este modo, se fotografía no solo el arte (arquitectura, pintura o escultura), sino todo aquello que pueda descifrar la codificación del cuerpo a analizar (por ejemplo los trajes, las fiestas populares, los oficios), lo que viene a determinar la diferencia o peculiaridad local. Es entonces Huntington un ejemplo claro del viajero y coleccionista fotográfico de finales del siglo XIX y principios del XX (del turista visual), aquel que parte de la idea básica de la documentación arqueológica del objeto, sin olvidar la documentación antropológica del mismo, situando ambos campos en un similar valor; es decir que, como interesado y conocedor de las posibilidades de la imagen fotográfica, en su construcción reflexiva le concede un protagonismo destacado a la cotidianidad de la sociedad, ya que posiciona este carácter como fuente fundamental de conocimiento. Como consecuencia de ello, se crea un gusto particular que va a ser clave para la conformación estructural de las representaciones fotográficas; y es que su predilección por esa comentada cotidianidad de mercados, ferias, fiestas, etc., va a ser decisiva para la colección de la Hispanic -siendo temas recurrentes tanto en las compras como en los trabajos de encargo realizados por sus colaboradores-. Un ejemplo de ello es que desde sus primeros ejercicios fotográficos en España, Huntington combina la arqueología con la etnografía; o sea que, cuando documenta las excavaciones arqueológicas no olvida capturar, igualmente, la cotidianidad de los trabajadores y sus familias, como acreditan sus piezas de 1898 (Lenaghan, 2009b: 219). Se hace evidente, por lo tanto, que la representación iconográfica que va a contener el archivo fotográfico de la Hispanic viene determinada por la ideología que su propietario proclama, abiertamente, al creer que la España auténtica es aquella que se vive, como ya hemos apuntado, fuera de los centros urbanos. Es un hecho trascendental, pues para entender el sentido final de 
la colección fotográfica tenemos que tomar esta idea como base preparatoria, tanto de la compra de material gráfico como de las futuras expediciones que fomentará desde la institución para documentar el país.

Ya se ha comentado que este filántropo tiene el principio vital de dedicar su fortuna al fomento y estudio de la cultura española, de conocerla en profundidad, obviando el análisis epidérmico de una sociedad para introducirse en la España desconocida (o menos conocida); un posicionamiento en el que la fotografía va a jugar su propio papel pues, como técnica moderna y herramienta eficaz de documentación, se convierte en matiz indispensable de todo este proyecto. Como afirma Lenaghan, la fotografía siempre fue valorada por él (no se debe olvidar que hacia 1887 ya poseía más de cuatro baúles repletos de este material) (Lenaghan, 2012: 19), ocupando un lugar determinado junto a pinturas y libros (Lenaghan, 2007b: 64), y siendo uno de los vehículos más eficaces para la divulgación de su interés por España (de hecho Huntington insiste en que los fondos fotográficos deben estar a disposición de los investigadores y utilizarse para las publicaciones de la institución) (Espinosa Fernández, 2018: 15). Reflejo de todo ello es que Huntington anuncia, en 1913, que la fundación debe poseer un archivo, siendo en 1928 liberado de la organización de las colecciones de la biblioteca y del museo cuando crea el departamento de Iconografía (Lenaghan, 2003: 20), en el que comparten espacio fotografías y estampas (Lenaghan, 2007a: 61); curiosamente, este coleccionista entendía estas dos modalidades representativas como objetos comparables y, por ello, veía lógico que estuvieran agrupadas en una misma sección (Lenaghan, 2003: 20). El crear un espacio determinado para ellas es producto de la evolución valorativa que experimentan las imágenes para Huntington; esto es, que las fotografías pasan de interesarle, exclusivamente, como fuente para sus publicaciones a convertirse, también, en documentos visuales con entidad propia, ahondando en la idea de que no solo el archivo sirva como reflejo del arte español sino también de sus costumbres (Lenaghan, 2004: 24), a modo de un programa enciclopédico.

Una vez se tiene clara la base temática en la que apoyar todo el discurso representativo de la colección fotográfica (aspecto por el que se va organizar el fondo y no por autoría) (Lenaghan, 2018a: 192), Huntington establece una estrategia de adquisición de la obra, fundamentada tanto en la compra de material como en la producción del mismo. Se trata de un sistema clave que esta institución utiliza para la consolidación y crecimiento rápido de su archivo, concretándose en tres fórmulas evidentes. La primera de ellas viene determinada por las aportaciones que él mismo efectúa tanto de su trabajo personal (realizó cientos de composiciones en sus expediciones como aficionado) (Espinosa Fernández, 2018: 15) como de las imágenes adquiridas en sus viajes o facilitadas por marchantes, como son las obras de Charles Clifford o Jean Laurent (Lenaghan, 2007b: 67); en el primer caso es difícil precisar con exactitud el número de obras que entregó a la Hispanic, ya que hizo depósitos irregulares, a lo que se suma que el sistema de catalogación empleado dio poca importancia a si provenían de su biblioteca personal (Lenaghan, 2007a: 62). La segunda fórmula, y una de las más interesantes, es la que viene establecida por el sistema de producción particular; hablamos de un grupo de imágenes efectuadas desde la propia institución a través de sus importantes expediciones subvencionadas tanto por agentes autónomos como por el personal de la Hispanic, siendo muy destacables las realizadas a partir de 1923, ya que fueron ejecutadas en exclusiva por las conservadoras y fotógrafas del centro -y es que Huntington com- 
pleta su archivo enviando a estas profesionales por todo el país (Lenaghan, 2014: 161)-; y la tercera y última viene condicionada por las donaciones, y así el repertorio crece gracias a los obsequios que recibe la Hispanic como, por ejemplo, el fondo del marqués de Vega-Inclán.

Bajo estos parámetros comienza todo un proceso constructivo que alcanza su máximo desarrollo durante los años veinte y treinta, tiempo en que la incipiente colección experimenta un notable aumento de sus piezas. Todo este contexto es un fiel reflejo de la decisión y compromiso que Huntington tiene por poner en marcha la siguiente fase de su plan museográfico; esto es, la de crear y poseer su propio archivo documental. Es una actividad compleja, todo un reto teórico y práctico, por lo que este investigador propone la contratación de expertos en el medio fotográfico. Una decisión trascendental que tiene como resultado la incorporación a la plantilla de la Hispanic Society de fotógrafos profesionales, en este caso de fotógrafas (especialistas claves para la resolución de tan importante tarea). De este modo, es contratada Ruth Matil da Anderson, autora que va a desempeñar un papel primordial en todo este proceso, pues ejerce como fotógrafa del museo desde 1921, y como conservadora de fotografía desde 1922 (Lenaghan, 2003: 27). Un rápido ascenso que es debido tanto a la falta de un personal cualificado, hasta su incorporación, como a que la llegada de esta realizadora a la fundación coincide con un tiempo básico de cambios y reorganizaciones internas (Lenaghan, 2004: 17). La elección de esta productora, como responsable de tales áreas, no es una mera coincidencia, sino un acto consciente de Huntington. La Hispanic buscaba una profesional del medio fotográfico con unas características determinadas y Anderson, en principio, cumplía las expectativas de la solicitud: era joven, estaba formada intelectualmente y era una fotógrafa experta con evidentes cualidades para el oficio, ya que había recibido las primeras lecciones técnicas de su padre Alferd Theodore Anderson (el cual era fotógrafo comercial), culminando su educación en la Clarence H. White School for Photography (Lenaghan, 2009a: 16), una importante institución norteamericana en cuanto a instrucción fotográfica se refiere. Con su llegada al centro comienza un capítulo significativo de valoración competitiva del trabajo de la mujer fotógrafa, por parte de este organismo, convirtiéndose su labor, como ya se ha apuntado, en el engranaje clave para la constitución y consolidación de tan deseado archivo. Y es que tanto ella como sus compañeras (conservadoras, bibliotecarias y fotógrafas), comandadas por el propio Huntington, van a desarrollar todo un protocolo de actuación efectivo en pro de la construcción de tal acervo documental (Lenaghan, 2003: 21).

De esta forma, desde los años veinte, se incorporan a la institución diferentes colecciones fotográficas de autores europeos del siglo XIX como Charles Clifford, Rafael Garzón Rodríguez, Casiano Alguacil o Jean Laurent; así como de firmas comerciales como la de Hauser y Menet (de los fotógrafos suizos Oscar Hauser Muller y Adolfo Menet Kurstinero) o la de Léon et Lévy (de los comerciantes Moyse Léone Isaac Lévy). A las que acompañan interesantes trabajos efectuados, en las tres primeras décadas del siglo XX, por fotógrafos (profesionales o amateurs) como Abelardo Linares, Mariano Moreno, Arthur Byne, Kurt Hielscher, Kurt Schindler, Anna Christian, Ruth Matilda Anderson o Margaret Jackson. Y un importante número de imágenes anónimas que, como algunas de las donadas por el marqués de Vega-Inclán, por ejemplo, cierran todo este proceso de consolidación física y conceptual del archivo fotográfico de la Hispanic, reuniéndose en definitiva un fondo documental de más de ciento cincuenta mil imágenes, que van a abarcar un amplio arco 
cronológico, entre 1860 y 1930 -toda una historia de la fotografía-, y en el que vamos a localizar interesantes producciones conectadas con la región de Murcia.

\section{MURCIA EN EL ARCHIVO FOTOGRÁFICO DE LA HISPANIC SOCIETY}

En este sentido, dentro del conjunto general hallamos más de trescientas fotografías relacionadas con este territorio del Levante español. A priori podrían parecer un número insignificante, teniendo en cuenta el volumen de tan vasta colección, pero la calidad histórico-plástica de las mismas las sitúa en un alto nivel expresivo, personalizándolas como obras referenciales de nuestra particular historia de la fotografía. Se trata, en definitiva, de un archivo fotográfico circunscrito, en este caso, a los años comprendidos entre 1862 y 1930, que es realizado por autores europeos y norteamericanos -profesionales y amateurs-; es decir, por una nómina de productores, altamente significativa, que queda definida por artífices de calidad como Charles Clifford, Jean Laurent, la firma comercial Léon et Lévy, Arthur Byne, Kurt Hielscher, Kurt Schindler, Anna Christian, Ruth Matilda Anderson y Margaret Jackson ${ }^{5}$.

\section{Gráfico 1 \\ FOTOGRAFÍAS DE FOTÓGRAFOS EUROPEOS Y NORTEAMERICANOS RELACIONADAS CON MURCIA EN LA HISPANIC SOCIETY OF AMERICA}

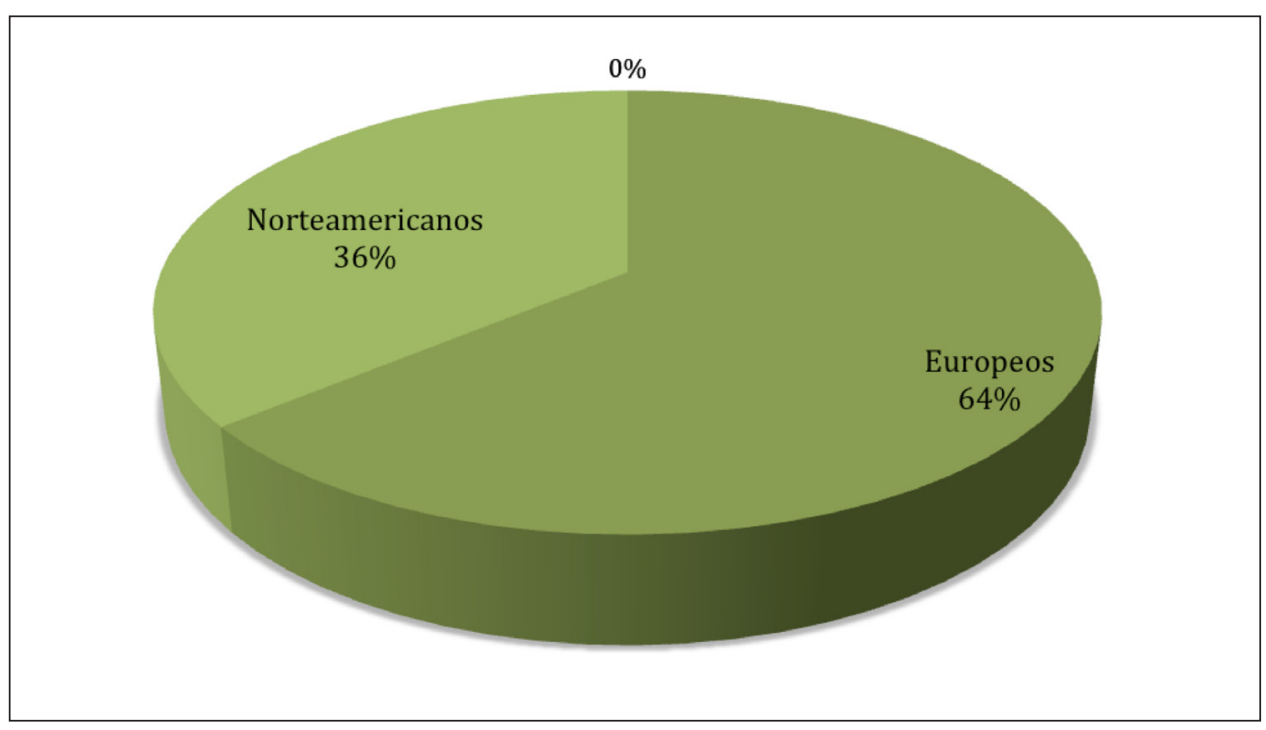

5 Junto a ellos localizamos tres autores españoles que aportan imágenes a la colección relacionadas, también, con la región de Murcia. De Sáez Martín la institución posee una fotografía de Totana, la cual se conserva bajo el título de «La Bastida. Totana». De Sánchez del Pando, una imagen con la denominación de inauguración del pabellón de Murcia. Y de Giménez, del que desconocemos más datos, tres representaciones de Caravaca de la Cruz, en las que se plasman diferentes fragmentos de la hoy Real Basílica-Santuario de la Vera Cruz. 
Si tenemos en consideración el proceso reglado (adquisición, producción y donación) con el que se construye el fondo fotográfico de la Hispanic, podemos establecer una línea argumental coherente histórico-cronológica que se inicia, lógicamente, en el siglo XIX. El primero de sus apartados, la adquisición, toma cuerpo de naturaleza y se estructura con la obra del fotógrafo inglés Clifford; un trabajo que, aun no siendo del primer autor en el que se fija Huntington, sí representa la imagen más antigua de España dentro de la colección, en cuanto a fotografía de la región de Murcia se refiere. Se trata de un productor imprescindible pues, como bien apunta Lee Fontanella, este es uno de los fotógrafos extranjeros que desempeña un papel trascendental dentro de la historia de la fotografía española (Fontanella, 1981: 58) ${ }^{6}$, siendo un pionero en la documentación de las modernas construcciones e infraestructuras del país, en aquel tiempo; o sea, que es un experto profesional que centra parte de su labor en retratar la España monumental y evolucionada del reinado de Isabel II (López Mondejar, 2005: 40). No obstante, la forma de fotografiar la España de la década de los sesenta del siglo XIX, y los intereses temáticos que muestra en las representaciones de las escenas, pese a tener un trasfondo comercial, son del agrado de Huntington, ya que coincidían plenamente con la imagen mental que este coleccionista desea para su museo ideal, en general, y su fondo fotográfico en particular. Una razón de peso por la que no duda en adquirir diferentes álbumes originales de este autor, consiguiendo entre ellos el volumen dedicado a Andalucía y Murcia. Un trabajo para el que fue seleccionado este fotógrafo por la corte, teniendo como encargo inmortalizar las visitas de la reina a estos territorios ${ }^{7}$; asunto que convierte a esta recopilación en un documento de gran valor para la región de Murcia ya que se incluyen, evidentemente, una serie de composiciones relevantes de la historia de la fotografía regional.

Así pues, en cuanto a esta zona del Levante español se refiere, la Hispanic posee de este imprescindible autor nueve fotografías, correspondientes al año 1862; seis de ellas atienden a la ciudad de Murcia, principalmente, a través de panorámicas generales de la capital y de vistas detalle, como la efectuada del arco de triunfo efímero construido para recibir a la reina Isabel II; o como las ejecutadas alrededor de la santa iglesia catedral de Santa María -la catedral de Murcia-, en las que se duplica con eficacia tanto la fachada principal como la puerta de los Apóstoles. Del mismo modo, y con similares matices, se localiza una serie de piezas que perpetúan a la ciudad portuaria de Cartagena, concretamente tres, presentando una interesante composición de toda la metrópolis y dos ejercicios que toman a su puerto como su centro escénico, quedando testificados para la historia su dársena y el navío Isabel II, atracado en el mismo. En consecuencia hablamos de unas imágenes que, al igual que las realizadas en la capital, transcriben con corrección el importante discurso plástico ejecutado por este creador en su propósito de documentar, profesionalmente, los lugares que visita.

Tras este viajero situamos la figura del también fotógrafo Jean Laurent. Un autor de origen galo que es, sin duda alguna, otro baluarte esencial para la historia de la foto-

6 Para un conocimiento más profundo sobre el personaje véase: (Fontanella y Kurtz, 1996) o (Fontanella, 1999).

7 El documento ha sido publicado en su integridad por la Hispanic Society, en 2007, a propósito de la exposición de este material en la fundación José Manuel Lara (Lenaghan y García de Cortázar, 2007). 
grafía europea en general y la española en particular ${ }^{8}$. A diferencia de Clifford, Laurent es un emprendedor que ejerce el oficio y vende series fotográficas; un empresario que forma parte del comercio de imágenes coleccionables, gracias a los nuevos sistemas de producción y venta de fotografías en su versión de postales. Es decir, un productor que sacia con su trabajo, y el de sus empleados o comisionados, el deseo social de posesión y conocimiento, a través de la comercialización de iconografías de diferentes territorios españoles (Díaz Francés, 2016).

A él le corresponde el honor de ser uno de los primeros artífices por los que Huntington se sintió interesado. De hecho, los trabajos de Laurent se sitúan entre los primeros adquiridos por este coleccionista, teniendo en consideración además que obtiene tanto material de este artífice que hoy día la Hispanic es uno de los ejemplos mundiales en cuanto a posesión de originales de este fotógrafo se refiere (Lenaghan, 2007a: 65). Probablemente, estos objetos llegan directamente de la mano del propio Huntington, pues es posible que los comprara él mismo en la tienda del fotógrafo tanto en Madrid como en París (ibid. : 62); y es que cuando él llega a España, la empresa de Laurent, aunque él ya ha fallecido, sigue en activo y sigue siendo aún un referente para los coleccionistas de imágenes etnográfico-culturales de España ${ }^{9}$. La acción podría parecer gratuita, sin embargo va tener una suma importancia en la construcción ideológica de la colección, ya que es la obra de Laurent el referente que marca las pautas estético-compositivas dentro del mencionado archivo, convirtiéndose en un ejemplo visual para el poseedor y, por ende, en un modelo en el que apoyar sus próximas adquisiciones, e incluso en un modelo en el que inspirar los trabajos generados desde la misma institución. Y es que las piezas de este fotógrafo, por su forma de atender a los paisajes, pueblos, arquitectura y tipos humanos de cada provincia española, le ayudan a Huntington a concebir una noción concreta del país, esa que va ser un arquetipo definitivo para él, siendo el dispositivo memorial que consolida la idea determinada de esta nación.

En cuanto a la región de Murcia se refiere, se localizan dentro de la colección un total de treinta y seis fotografías, fechadas entre 1870 y $1871^{10}$. Se trata de unas imágenes que aluden a poblaciones como Murcia, Cartagena, Lorca, Cieza, Archena y Monteagudo; la cantidad de obras y de lugares seleccionados son un fiel reflejo del interés del coleccionista por este autor. La ciudad de Murcia está representada en veintiuna de ellas, centrando su atención tanto en su característica «huerta» como en su metrópolis; así, se hallan vistas del campo y sus trabajadores en diferentes modalidades: por ejemplo, junto a sus aperos y sus carros con la cosecha. Del mismo modo, son fotografiados los monumentos circundantes a la capital, como es el santuario de Nuestra Señora de la Fuensanta, del que se realizan distintas vistas; o aquellos que, anclados en el centro urbano, lo encarnan y personifican, como son la fachada de la iglesia de Santiago o el imponente grupo de imágenes que

8 También para la historia de la fotografía en Murcia, sobre este particular véase: (Vázquez Casillas, 2008).

9 No todas las imágenes de este autor llegaron en el mismo momento a la Hispanic, pues algunas lo hacen a través de donaciones, como las aportadas por el marqués de Vega-Inclán (Lenaghan, 2018a: 193).

10 La llegada de la casa Laurent a Murcia sucede hacia 1870-1871. Es muy posible que el fotógrafo que viene a esta tierra, en nombre de la empresa, sea Julio Arnaud, ejecutando las imágenes en representación de la firma comercial. Este se encuentra en 1870 realizando fotografías para Laurent en Valencia (Teixidor Cárdenas, 2003: 29). 
reproducen a la catedral de Murcia; una estructura artística que es diseccionada en todas su partes, encontrándose composiciones de todas sus portadas y, cómo no, de la capilla de los Vélez. Junto a todas ellas, igualmente, este artífice desarrolla todo un programa iconográfico que tiene como centro compositivo la propia masa arquitectónica de la localidad en su conjunto; así, las vistas globales del río Segura, con toda la edificación al fondo, se combinan con detalles de sus calles. Algo similar sucede con la ciudad de Cartagena, un enclave fotografiado con esmero por Laurent y del que la Hispanic conserva un total de diez fotografías. En este caso, el municipio portuario es analizado, objetivamente, por una activa e interesante variedad de perspectivas generales en las que se percibe su complejidad urbanística, sintiendo predilección, por ejemplo, por sitios como el Arsenal tanto en tomas amplias como en fragmentos de su propia entrada. Y, como sucede con la documentación visual dedicada a Murcia, Laurent pone su atención en aquellos aspectos peculiares e identitarios que proyectan los matices socioculturales de Cartagena; nos referimos al puerto, un espacio comunitario que es registrado, fotográficamente hablando, en todo su proceso, pues el realizador enfatiza con detalle su entrada y la construcción del rompeolas del muelle de la Curra, del que aporta diferentes miradas, al tiempo que representa, también, el dique flotante con la fragata Arapiles. Igualmente son interesantes, aunque con un número inferior de instantáneas, las dedicadas a testimoniar localidades como Cieza, de la que tan solo se conserva una vista general de la ciudad y otra de un puente. De Monteagudo la institución posee dos imágenes que, asimismo, certifican tanto el municipio en su paisaje característico como su interesante castillo. Mientras que de Archena se deja testimonio de su identidad a través de una composición de sus baños termales; y de Lorca con una toma de su pantano.

Tras este imponente conjunto, cerrando el siglo XIX, se sitúa la colección de trabajos de la firma comercial, también francesa, Léon et Lévy. Una empresa que operará bajo diferentes nombres, correspondiendo estas fotografías a la tercera y cuarta denominaciones, por lo que pueden fecharse las mismas entre 1870 y 1895 (Cameron, 2008: 850) ${ }^{11}$. Como sucede con Laurent, producen un objeto democrático consumible, en este casouna vasta biblioteca de vistas estereoscópicas (aunque también postales) en las que se recogen aspectos artísticos y culturales, mayoritariamente europeos. Es un material fascinante que se hace del agrado de todo tipo de coleccionistas, siendo por ello atractivo para un personaje como Huntington, que adquiere numerosas de sus imágenes para la Hispanic, atraído tanto por la excelente calidad de sus representaciones como por la política visual ostentada en ellas.

En cuanto a la región de Murcia se refiere, la institución posee veinte obras de esta compañía, todas ellas relacionadas con su capital; unas piezas que quedan fechadas entre 1885 y $1890^{12}$. El conjunto deja testimonio de una localidad en pleno desarrollo vital a través de calles como Trapería y Jabonerías; de plazas como Santa Catalina o Santa Isabel; y de arquitecturas y monumentos como la plaza de toros, el Teatro Romea, la iglesia de Santo Domingo, el convento de la Misericordia, el Ayuntamiento o las ruinas de los baños árabes; y, cómo no, al igual que todos los viajeros fotográficos que llegan a esta urbe, el archivo pone igualmente su objetivo sobre la catedral de Murcia, capturando

11 Para un conocimiento más profundo véase: (Mccauley, 1994) o (Voignier, 1992).

12 La fecha viene determinada por la empresa depositaria del fondo de Léon et Lévy en la actualidad, la agencia Roger Viollet. Sobre este particular véase: http://www.roger-viollet.fr/fr (consulta: 03/12/2018). 
tanto su exterior como su interior, para dejarnos imágenes clásicas de la puerta de los Apóstoles, la puerta y el interior de la capilla de los Vélez, la puerta de la Sacristía, la nave central y las laterales, etc.

\section{Gráfico 2}

\section{FOTOGRAFÍAS DEL SIGLO XIX Y DEL SIGLO XX RELACIONADAS CON MURCIA EN LA HISPANIC SOCIETY OF AMERICA}

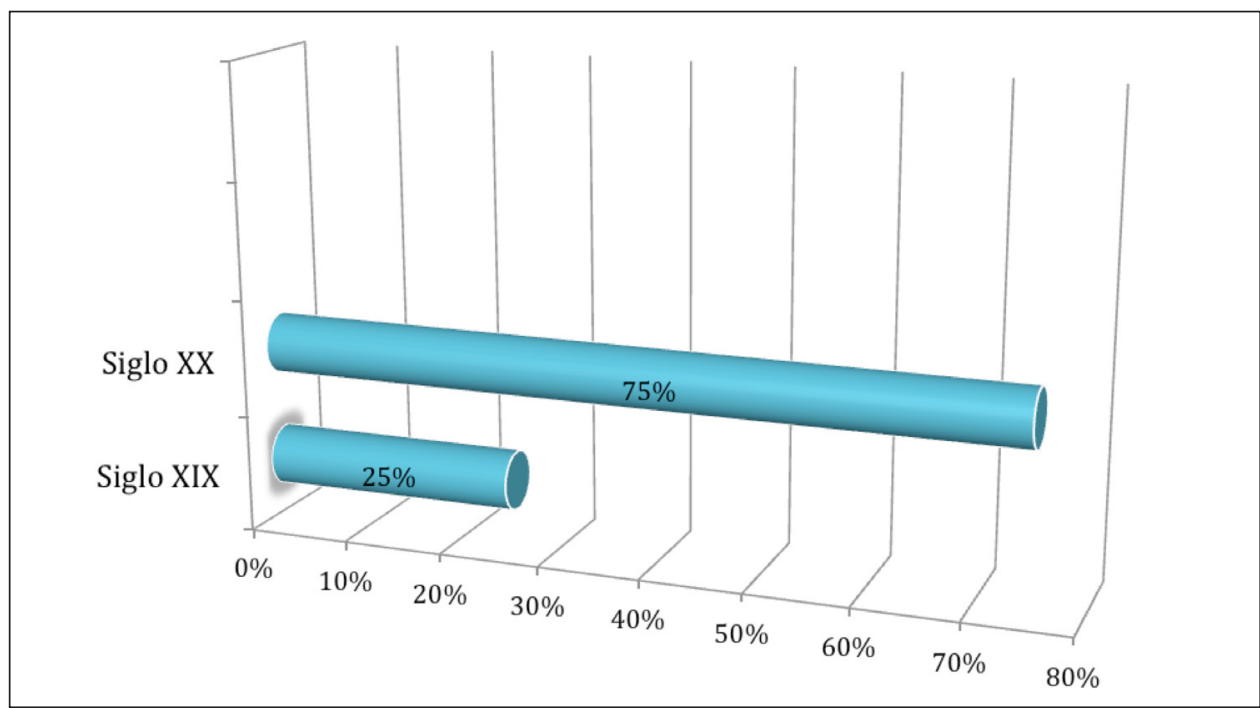

Tras estos tres excelentes ejemplos del siglo XIX encontramos una serie de autores del siglo XX que, del mismo modo, contribuyen al enriquecimiento teórico visual del fondo fotográfico. Kurt Hielscher y Anna Christian son los dos artífices que, con características distintas a sus antecesores, cierran este apartado de las adquisiciones fotográficas relacionadas con Murcia por parte de la Hispanic. Y es que, a diferencia de Clifford, Laurent y Léon et Lévy, Hielscher y Christian son fotógrafos amateurs, realizadores que con su particular naturaleza experimentan el concepto del viaje por el territorio nacional. De esta forma, y bajo una ideología de la experiencia visual íntima, transitan por el país documentando su idiosincrasia con formulaciones desiguales que van a depender, pues, de la propia conceptualización de su acción expedicionaria.

En este contexto de ordenación cronológica-creativa situamos, en primer lugar, al alemán Kurt Hielscher. Antes de analizar el trabajo de este ejecutante sobre Murcia, debe tenerse en consideración que el proyecto de Huntington, durante la década de los veinte, adquiere un protagonismo social importante; esto es, que se hace conocida su intención de construir su propio fondo documental sobre España. Un hecho que tiene como consecuencia que marchantes y distribuidores de arte, atraídos por la posibilidad de negocio, le ofrezcan a este coleccionista el material gráfico que sobre tal temática poseen. Ejemplo claro de ello es la llegada a la Hispanic de la obra de 
Hielscher, conjunto que es ofertado y vendido a Huntington por el marchante Berthold Hemme (Lenaghan, 2007a: 63), así como diferentes fotografías de la firma comercial, también alemana, Foto Archivo Folkwang en Essen (Lenaghan, 2007b: 68) ${ }^{13}$. Luego, tras el ingreso en la institución del repertorio fotográfico de Arthur Byne, autor que analizaremos más adelante, se incorpora al archivo la imponente y característica obra de Kurt Hielscher. Hemme le proporciona a la Hispanic la colección completa, unas 1600 piezas realizadas entre 1914 y 1919 (Almarcha Núñez-Herrador y Lenaghan, 2012: 319), con lo que esta se convierte en la depositaria global de esta significativa fuente histórico-documental. De todas ellas tan solo pertenecen a la región de Murcia dieciocho; no obstante, por su interpretación de la zona son de un valor incalculable para nuestra historia de la fotografía. Y es que Hielscher es un estudioso que mira a nuestro país con ojos románticos, bajo esa búsqueda del territorio desconocido y sorprendente. Su profesión de educador y su deseo de viajar tienen como consecuencia que durante la I Guerra Mundial se encuentre en España, permaneciendo en ella hasta el final del conflicto (Hielscher, 2007). Una estancia que se desarrolla entre trabajos esporádicos como docente y la realización de imágenes de todos los territorios que visita, derivándose de esta última acción su libro, de 1922, Das unbekannte Spanien (Hielscher, 1922) (publicado en español bajo la denominación de La España desconocida). Se trata de un importante volumen en el que plasma su visión particular del arte y la etnografía de una España idealizada en sus estándares clásicos. Una visualidad conceptualizada que es, claramente, manifiesta cuando apunta en su introducción: [...] España es un gran museo de arte abierto, que encierra la riqueza cultural de las épocas y los pueblos más diversos [...] (Lenaghan, 2004: 52).

Dentro de este contexto, proporciona sobre la región murciana documentos excepcionales que testifican el estado de esta zona del Levante entre 1914 y 1919; periodo que queda ejemplificado en sus miradas a localidades como Murcia, Lorca y Monteagudo. De todo el conjunto siete escenas corresponden a la ciudad de Murcia; en ellas se representan tanto vistas generales de su entramado constructivo como detalles de sus jardines; pero también de su inmutable catedral, de la que nos ofrece imágenes globales y fragmentos de su capilla de los Vélez, así como de su imponente torre. Por su parte, Lorca queda representada a través de cuatro fotografías en las que se recogen, mediante panorámicas abiertas y detalles, su entramado arquitectónico y el palacio de los Moreno Rocafull. Por último, pero no menos significativo, encontramos seis composiciones que detallan la localidad de Monteagudo; su huerta y el castillo acaparan todos las representaciones, siendo este último un edificio que le causó una importante impresión, como queda acreditado al ser la única imagen incluida de esta región en su publicación La España desconocida (Hielscher, 2007).

Con un mismo carácter de turista visual, pero a modo ahora de viaje iniciático, situamos el trabajo de Anna Christian, la autora norteamericana que cierra este periplo de adquisiciones. Su experiencia, aunque coincidente en cuanto a independencia de búsqueda, es totalmente distinta a la de Hielscher, ya que esta realizadora conceptualiza

13 De la editorial Folkwang Verlag se localizan en la colección tres piezas de autoría anónima; estas corresponden a la fachada de la catedral de Murcia y a la iglesia de San Juan de Dios: alzado y planta; unos trabajos que quedan registrados en el libro, de 1908, Geschichte des Barock in Spanien (Schubert, 1908: 279, 376 y 377 ). 
previamente sus obras -incluso antes de realizarlas- mediatizada por la pintura (e ideas sobre España) de Joaquín Sorolla; una actitud, que por otra parte, se percibe en los ejercicios efectuados por las propias trabajadoras de la institución (Lenaghan, 2004: 28-29). Tenemos que tener en consideración que Christian es uno de esos ejemplos de mirada ajena, de exploradora visual que documenta, atraída por su cultura, las tradiciones de un pueblo. Ella pertenece a una familia acomodada y es conocedora de los procesos fotográficos, por lo que nos encontramos ante una estudiante de arquitectura que emprende un recorrido intimista en busca de una sociedad alejada de su propia cotidianidad. Así, en 1915 comienza un periplo por España inducida, como ya hemos apuntado, por el pintor Sorolla; un artista al que conoce personalmente en Nueva York y que le anima a que viva su propia experiencia por la península, fotografiando los diferentes lugares que él mismo había diseccionado en sus obras (Lenaghan, 2014: 166). De hecho sus fotografías van a reflejar, sintomáticamente, el impacto que le suponenlas pinturas de este autor (ibid. : 169). Un matiz significativo que no debe olvidarse, pues todo este contexto refleja un asunto crucial que tiene como consecuencia que esta fotógrafa amateur recale en Valencia, extendiendo su labor desde este enclave.

Huntington, amante en profundidad de la cultura española en general y de la obra de Sorolla en particular, se siente interesado por el trabajo de esta creadora desde el primer momento; no hay que dejar de lado el dato trascendente de que él mismo financia la exposición de Sorolla en el centro y de que le propone además la decoración de una de sus salas; de hecho es tal su fascinación que al año siguiente de realizar Christian su viaje fotográfico, le encarga a ella una exhibición de sus imágenes. Es tan grande el éxito de esta muestra, y tal es el deseo de posesión de las obras, que en 1917 la Hispanic adquiere seiscientas treinta y una de sus composiciones, a las que en 1922 se suman ciento seis más (Lenaghan, 2007b: 74). Pese a su formación como arquitecta no sentirá un apego especial sobre este tipo de estructuras a la hora de realizar sus trabajos, aunque lógicamente es uno de sus temas de representación importantes, como son por ejemplo las casas de la gente sencilla del ámbito rural, siempre observándolas bajo una mirada interesada en sus matices antropológicos.

Dentro de la colección general se conservan, en este caso, veintiuna escenas de la región de Murcia, las cuales tienen como protagonista principal a Murcia y su barrio Espinardo. En cuanto al centro urbano se refiere, esta autora lo representa a través de dieciséis imágenes que diseccionan, por un lado, calles como la del Príncipe Alfonso y, por otro, diferentes arquitecturas, que son sin duda ejemplo innegable y referente de la ciudad en aquel tiempo. Así quedan retratados inmuebles como el edificio del Contraste en distintas tomas fotográficas; la casa del conde de Roche, tanto en su exterior como en su interior: pasillo, patio-jardín o escalera; la casa Huerto de las Bombas, que es igualmente fragmentada en importantes panorámicas y detalles; o, por último, la casa de los Celdrán. Mientras tanto, a Espinardo le corresponden cinco composiciones; en esta ocasión, Christian pone su punto de mira en el medio agrícola para documentar temas etnográficos relacionados con el cultivo autóctono y las construcciones autosustentables (y ecológicas) de barro y paja -en diferentes vistas-, reproduciendo su exterior e interior, sobre todo centrándose en sus austeras cocinas; al tiempo que constata el uso del bambú, un material importante, tanto para el cerramiento externo de la casa como para el huerto o corral. 
El segundo de los apartados, la producción propia, fue una de las modalidades más interesantes a través de las que se aumentó el archivo fotográfico, ya que estaban regladas directamente por el ideario de su benefactor: unos parámetros precisos que vienen a cumplir su sueño de construir su propio fondo. En este sentido, y bajo el halo del mecenazgo filántropo, Huntington toma la decisión de patrocinar este tipo de actividades formativas, motivado por una convicción profunda de creer que son estrictamente necesarias para la adquisición del conocimiento. Una determinación que tiene como trasfondo el dar a sus trabajadores la posibilidad de vivir la acción y conseguir con ella el conocimiento en el propio terreno o medio de estudio. Inicialmente, estas son realizadas por investigadores independientes pero, transcurrido el tiempo, y tras las negativas experiencias con estos realizadores, a partir de 1923 son ejecutadas en exclusiva por la plantilla de la propia Hispanic (Lenaghan, 2007a: 63); esto es, por las trabajadoras que él elige y contrata, por sus cualidades profesionales, para configurar el equipo de la institución.

Una de las primeras financiaciones independientes es la destinada al arquitecto norteamericano Arthur Byne -el cual es acompañado (y ayudado) para realizar la misma por su mujer Mildred Stapley Byne-. Estamos ante un personaje controvertido que fotografía el patrimonio español como un acto de reconocimiento significativo, mientras que tiempo después se convierte en un traficante de este arte, ejerciendo una actividad expoliadora brutal sobre el mismo (Merino de Cáceres, 2011: 240). De este modo, tras la incorporación al fondo del material de Clifford, Laurent o Léon et Lévy, llegan al archivo los diferentes trabajos del mencionado arquitecto; de hecho son las primeras piezas que ingresan de forma oficial en la colección (Lenaghan, 2007b: 66). Se trata, por lo tanto, de un artífice que va a realizar varias expediciones a España durante los años 1915, 1917 y 1918 (Lenaghan, 2007a: 63), aportando más de tres mil imágenes al repertorio (Lenaghan, 2003: 25). Su formación es un condicionante con relación a las composiciones que efectúa; es decir, que la elección de sus iconografías son acordes a sus necesidades profesionales, razón por la que sus fotografías prestan una mayor atención a temáticas arquitectónicas. Un asunto que, sin embargo, no incomoda a Huntington, que va a ver en ellas, al igual que en las adquiridas con anterioridad a maestros del siglo XIX, un modelo en el que inspirarse y una guía en la que apoyar el trabajo producido por sus fotógrafas y conservadoras, a la hora de continuar con la consolidación de la recopilación documental.

Byne formaba parte de la Hispanic desde 1915, desarrollando actividad colaborativa en ella hasta 1921 (Núñez-Herrador y Lenaghan, 2012: 320). Como labor, el matrimonio se propuso estudiar y fotografiar la arquitectura y el arte de los distintos sitios en los que estuvieron en sus viajes, teniendo la intención de crear, con tales imágenes, un fondo especializado en la disciplina arquitectónica. Así pues, todas aquellas representaciones que atañen a Murcia van a tener como sentido conceptual y reflexivo esta materia.

Dentro de todo el conjunto efectuado por este autor, propiedad de la Hispanic, se localizan un total de siete fotografías ejecutadas en la ciudad de Murcia. Como es normal, y en consonancia con los intereses profesionales y personales de Byne, todas ellas van a girar en torno a la temática mencionada, por lo que elige como protagonista de su trabajo a la imperecedera catedral de Murcia, convirtiendo su monumentalidad en eje vertebral y expresivo de sus obras. Una vista general del primordial complejo es acompañada por 
cuatro tomas que documentan en esencia la magnitud de la torre; al tiempo que se dedica también a transcribir, visualmente, aspectos concretos como un fragmento de la fachada o la rejería de sus ventanas. Todas ellas son un claro ejemplo y reflejo del modus operandi de este realizador, que encuentra en la arquitectura artística española el campo imprescindible de expresión para sus pretendidas investigaciones futuras.

Junto a este situamos, por tratarse de un estudioso independiente, la obra ejecutada por el alemán Kurt Schindler; un compositor y experto en folclore español al que Huntington no duda en sufragar algunas de sus campañas de indagación etnográfica por España (Espinosa Fernández, 2016: 626). Se trata de unos viajes en los que este intelectual dedica su tiempo a recopilar aspectos relacionados con la tradición musical española (Katz y Manzano Alonso, 1991), al tiempo que fotografía la idiosincrasia del país; luego, ejerce como documentador con su cámara de todo tipo de celebraciones populares, en las que se realizan diferentes acciones de canto, danza y ritos en general; no olvidando también registrar los paisajes y las arquitecturas de la zona. Evidentemente, estamos ante un fotógrafo circunstancial, motivado por su interés cultural, un matiz que hace que sus imágenes no presenten rasgos profesionales (Lenaghan, 2007b: 69), incidencia que sin embargo no menoscaba la importancia de las mismas como fuente de conocimiento. Todo este ejercicio lo efectúa entre 1928 y 1935, siendo cedidas a la Hispanic en 1937 (Espinosa Fernández, 2016: 626). En cuanto a la región de Murcia se refiere, este musicólogo la retrata a través de cuarenta y ocho ejercicios en los que aborda escenas de ciudades como Murcia, Cartagena y Lorca. A diferencia de otros productores, posiciona a Lorca como la máxima protagonista de sus piezas. A la capital murciana le corresponden seis tomas, con las que este analista confecciona una visión expresiva tanto de aspectos arquitectónicos -como es el caso ilustrativo de la catedral de Murcia-como sociales -como son sus diferentes representaciones de las hijas del sacristán-. Por su parte, a Cartagena le dedica un total de quince composiciones. Como sucede con Murcia, este autor se siente interesado por variados asuntos sociales y constructivos de la localidad, fusionando ambos elementos iconográficos en sus imágenes. Y es que este investigador atiende a la vida que se desarrolla en los entornos que visita. Así, por ejemplo, aprovecha la documentación de la plaza de la Tronera, a través de vistas y detalles, para dejar testimonio de las jóvenes que portan jarras de agua. Algo similar sucede cuando deposita su objetivo en aspectos tan personales de la metrópoli como es su puerto, el cual es diseccionado mediante varias perspectivas abiertas, con las que mira tanto al mar como a su contexto arquitectónico;sin dejar de lado el componente humano que lo habita, en este caso representando a los marineros en el desarrollo de una celebración de un día festivo.

En cuanto a la ciudad de Lorca, en los veintisiete trabajos realizados repite el mismo sistema operativo que en los anteriores municipios, con lo que monumentos como el castillo, la colegiata de San Patricio -catedral-y algunas casas palaciegas son representados con distintas perspectivas atestiguando su monumentalidad. Unas imágenes que tienen como compañía diferentes escenas cotidianas del devenir de la propia sociedad, ejemplificada en esta ocasión tanto por las mujeres que venden y compran en el mercado como por los niños que transitan libres por los inigualables espacios de la zona. En ambos casos se trata de obras generales que, de forma notarial, dejan testimonio de los seres humanos que encuentra en su periplo viajero. 


\section{Gráfico 3}

\section{FOTOGRAFÍAS DE LAS CIUDADES DE LA REGIÓN DE MURCIA REPRE- SENTADAS EN EL ARCHIVO FOTOGRÁFICO DE LA HISPANIC SOCIETY OF AMERICA}

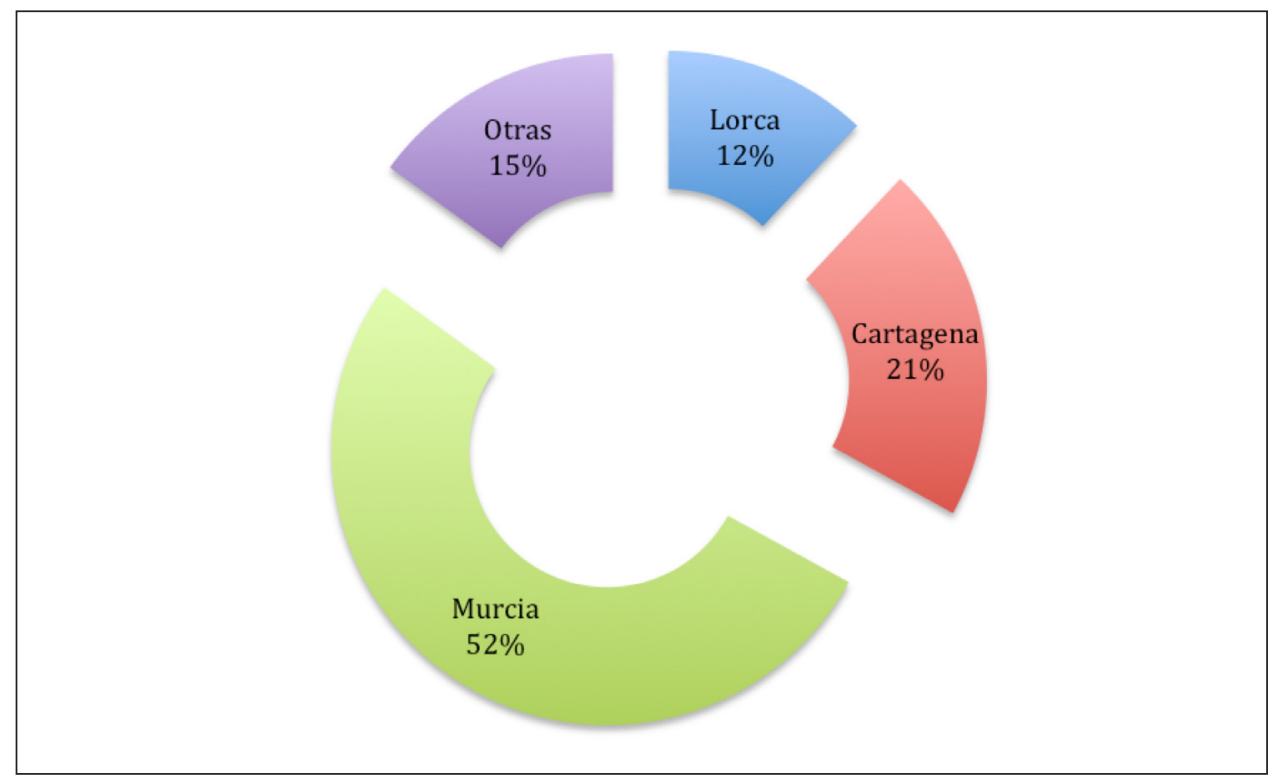

Junto a estas interesantes experiencias documentadoras (independientes), se sitúan las expediciones que la Hispanic fomenta desde el año 1923. Un tiempo en el que Huntington decide completar su archivo, mandando a sus propias conservadoras y fotógrafas a realizar tal labor (ya que en ocasiones se hace ciertamente complejo el adquirir imágenes de zonas remotas del país) (Lenaghan, 2017a: 66). Como norma reglada suele tratarse de un pequeño grupo de mujeres que inicia su particular travesía española siguiendo la ruta marcada por el propio Huntington (Espinosa Fernández, 2016: 618). La fórmula para tal fin es la expedición investigadora a España, de nuevo subvencionada. Este filántropo pensaba que el conocimiento sobre la cultura española sería más efectivo gracias a las publicaciones de sus colaboradores (ibid. : 610), de ahí la importancia del viaje pedagógico. En este sentido, Huntington aspira a que sus trabajadoras reciban la misma formación que él había experimentado en su juventud durante sus estancias en el extranjero. Él mismo apunta sobre este particular: [...] El personal deberá conocer obras y refranes y haber conocido a las criaturas autóctonas próximas a los hombres, desde la mula hasta la chinche. Buscarán una palabra y sus escurridizos significados como un inglés busca al zorro entre la maleza; deben tapar la madriguera de salida $y$ volver cabalgando con el trofeo. Entonces pueden escribir sobre su España[...] (Lenaghan, 2007b: 66). Por sus palabras se hace evidente que valora en profundidad la experiencia directa didáctica; es decir, el encuentro cara a cara con la cultura a estudiar, 
razón importante por la que las envía a recorrer, conocer y fotografiar el país (Lenaghan, 2003: 20) -una predicación tajante que él mismo había experimentado en 1892, 1896 y 1898, en sus diferentes viajes a España (Espinosa Fernández, 2016: 611)-. Este tipo de estancias eran consideradas por la Hispanic, entonces, como viajes de estudio; esto es, se concebían como una de las «obligaciones» profesionales de las operarias de la institución. Viajar y experimentar España, en consecuencia, era parte de la formación y del aprendizaje ordinarios. Un hecho que viene determinado porque entendía la investigación como una experiencia completa y la única satisfactoria (Lenaghan, 2017a: 63); o sea, como un enseñanza global y no como una expedición exclusivamente fotográfica, pues en el fondo se trata de entrar en contacto (en profundidad) con la cultura y la forma de vida de la población. Por eso, este tipo de actuaciones, a la postre, van a ser trascendentales tanto para el funcionamiento de la institución, por el conocimiento profundo que se adquiere de España, como para la conformación del archivo documental, ya que muchas de las fotografías que posee la fundación provienen de estas acciones - de las cuales, materialmente hablando, no solo obtenía el positivo fotográfico sino también la matriz, los negativos-. Tal es su repercusión que pueden cuantificarse por miles las aportaciones de imágenes conseguidas en estas estancias;travesías que solían durar entre cuatro meses y un año (por ejemplo, Ruth Matilda Anderson llega a generar 14. 000 piezas individualmente (Lenaghan, 2007a: 63), utilizando algunos complejos procedimientos como el autocromo (Lenaghan, 2009c: 69), a lo que se suman las diferentes compras efectuadas a fotógrafos locales).

Esta primera expedición, de 1923, viene a ser, por su primacía, un itinerario de prueba, un ensayo de cómo deben formularse las investigaciones y el contacto con España (ibid. : 73). Así pues, nos encontramos ante el inaugural viaje organizado para el personal de la institución, estando compuesto el equipo por Catherine Allyn, Anna Pursche y Ruth Matilda Anderson, la única fotógrafa profesional de las tres. Es un desplazamiento preparatorio, educativo y básico, para los diferentes campos de estudio de las colaboradoras (Espinosa Fernández, 2016: 620). En este sentido, este tipo de estancias se organiza de forma genérica para una pareja o grupo, nunca más de cuatro. En su desarrollo se aportan más de setecientas fotografías realizadas, principalmente y como es lógico, por Anderson. No obstante, sus compañeras también colaboran con la ejecución de diferentes representaciones experimentales, aunque es difícil precisar la autoría de las mismas, pues se catalogaron por la fecha de la expedición y no por la creadora. También, con el propósito de cubrir ciertas lagunas del fondo, se adquieren imágenes en diferentes archivos comerciales; una acción habitual en este tipo de experiencias, ya que se aprovecha tanto el talento de las trabajadoras como el de los fotógrafos autóctonos, a los que se les compra sus postales comercializadas o fotografías ex profeso.

Como ya se ha apuntado, el viaje tiene una duración de varios meses; en este caso, unos cinco, aproximadamente. Su entrada por Andalucía, y tras pasar un tiempo prudente en ella, tiene como consecuencia que continúen su periplo por la costa mediterránea, llegando a Murcia. La elección de los destinos viene determinada por el interés y la necesidad de la Hispanic de conseguir un material específico sobre temas y lugares que preocupan a su fundador. Por ello, las imágenes que corresponden a la zona murciana son un fiel reflejo de la ideología de Huntington; unas obras que proyectan subjetiva- 
mente sus principios: aquellos que se rigen por la idea de fragmentar y documentar visualmente el arte, la cultura y la vida de los diferentes territorios españoles. De este modo, en esta expedición van a tener un peso específico, en general, aquellas composiciones que muestran un carácter etnográfico, pues son de gran importancia para la fundación por representar la cotidianidad de los habitantes locales; un hecho que viene determinado porque técnicos como Byne habían realizado un importante conjunto de fotografías arquitectónicas, obviando la vida de los lugareños, lo que facilita a productoras como Anderson el poder dedicar más trabajos documentales a la población (Lenaghan, 2009b: 225). Eso sí, renunciando a lo netamente artístico, sin olvidarlo en el fondo, en beneficio de la transcripción notarial del día a día de los individuos y de la descripción meticulosa de los temas elegidos (Lenaghan, 2004: 13). Todo este encargo es un asunto complejo por lo que para desarrollar el trabajo van a tener en cuenta diferentes lecturas y revistas ilustradas, al tiempo que van a tomar como referente elemental los propios consejos de la ciudadanía, en general, y de los fotógrafos locales, en particular, que a modo de informantes son de gran ayuda para extender y completar su labor (Espinosa Fernández, 2018: 21).

En cuanto a la región de Murcia se refiere, dentro del fondo originado por esta expedición coral se localizan un total de treinta y cinco imágenes que atienden en sus composiciones tanto a Murcia como a Cartagena. En este sentido, a la capital murciana le dedican veinte fotografías, en las que encontramos un protagonismo absoluto de la sociedad, su trabajo y su cotidianidad; un matiz sintomático de los intereses de la institución en este tiempo, por lo que, aparte de las heterogéneas vistas panorámicas de calles y de detalles de callejones, patios o cornisas -así como de la catedral o de la iglesia de Jesús (imágenes siempre obligadas)-, se halla un sugestivo conjunto en el que el ciudadano es retratado en su espacio; es decir, en el que el habitante es el protagonista directo. Tal es el interés socio-antropológico en las mencionadas representaciones que el hombre es captado como tipo icónico, como elemento realista y autóctono; y es que no está tratado románticamente, sino presente en ellas, dejando testimonio y evidencia de su devenir a través de diferentes escenas callejeras. Ahora los fotógrafos buscan el carácter cultural de Murcia, y no una idealización, y depositan su objetivo en asuntos tan trascendentales, por ejemplo, como la sericicultura, abordando tanto el cultivo del gusano de seda como la extracción de la misma. Unas manifestaciones realistas que se acompañan, también, de una importante mirada al trabajo del esparto o cestería, así como al duro oficio de las lavanderas, las cuales son observadas valorándolas no solo como sujeto en su trabajo, sino también como sujeto en su espacio de desarrollo. Mientras tanto, sobre Cartagena se realizan quince composiciones. Como sucede con Murcia, en el municipio portuario se presta mayor importancia al trasunto humano, a la vida en plena acción. De esta forma, y aun localizándose elementales obras relacionadas con la infraestructura del puerto - su rompeolas, su muelle o el faro-, se deposita la visión más significativa en los trabajadores de la zona. Y es que, junto a vistas de la metrópoli -como, por ejemplo, el Gobierno Militar-, se despliegan unas llamativas piezas que retratan lavanderas y, cómo no, vendedores y vendedoras de pescado junto a sus transportes y puestos. Unas imágenes que son acompañadas por distintas escenas callejeras donde de nuevo el habitante desempeña su propio papel. Por lo expuesto, queda claro que esta primera 
experiencia de viaje supone un punto de inflexión importante para la composición y rumbo del fondo fotográfico de la Hispanic, al tiempo que también es crucial para el desarrollo personal de sus propias colaboradoras y fotógrafas, pues tienen, como es el caso de Anderson, la oportunidad de poner en práctica sus conocimientos fotográficos en beneficio de la institución (ibid. : 16).

Aunque a partir de este instante se realizan otras incursiones a España, no es hasta la expedición de 1929 cuando de nuevo vuelven a recorrer nuestra región las trabajadoras de las Hispanic. En esta ocasión, se trata de un viaje de estudio compuesto por Adelaide Marie Meyer y Ada Marshall Johnson, a las que acompaña Margaret Jackson, la única fotógrafa profesional de este equipo y otra de las colaboradoras responsable del aumento y consolidación de este fondo. Su llegada a la fundación se produce en el año 1927, siendo contratada en concreto para tal oficio, ya que en ese tiempo era una autora aventajada que conocía a la perfección el medio fotográfico. Todas juntas acometen un trayecto iniciático que las lleva a recorrer diferentes zonas de España, desde 1929 a 1930, efectuando investigaciones y fotografías, pero también, y en mayor medida, comprando material gráfico para completar su archivo. Es esta una razón evidente por la que tan solo se encuentran en este ejercicio nueve composiciones que atienden, directamente, a Murcia y Cartagena. En ambos casos el peso representacional viene marcado por su carácter antropológico. A la capital le corresponden siete imágenes que testifican el devenir social, ahora caracterizado por el ambiente y concepto del «mercado» (entendido como denominación de la venta callejera). Puestos de hilos y verduras, comerciantes en pleno desarrollo de sus labores y clientes en su cotidianidad, son expuestos como ejemplos paradigmáticos de una tipología humana contemporánea. Unas escenografías a las que se suman retratos de las propias expedicionarias, en su personal e íntimo periplo, y ciertos matices de nuestra cultura, como es el detalle de un coche fúnebre cumpliendo su función. Y al igual que sucede en esta localidad, en Cartagena se hace lo propio, captando para el futuro como memoria visual, en dos tomas, a aquellas personas que trabajan en el puerto, ejerciendo su quehacer en el proceso de remendado de las redes de pescadores.

Del mismo año, 1929, es el último viaje en el que encontramos trabajos fotográficos relacionados con la región de Murcia. Se trata de una expedición anómala, pues aunque es llevada a cabo por personal de la Hispanic, tiene la peculiaridad de, por un lado, estar ejecutada de forma exclusiva por Ruth Matilda Anderson; y, por otro, de no estar realizada físicamente en esta zona del Levante; y esto es posible porque las fotografías son plasmadas en el Pabellón Regional de Murcia y Albacete de la Exposición Ibero-Americana, organizada en Sevilla en el mencionado año. Como ya se ha comentado, Anderson es una de las piezas claves para el desarrollo y consolidación del fondo fotográfico. Curiosamente, y aunque emprende diferentes expediciones, a partir de 1923 renuncia en ellas a fotografiar las zonas orientales y meridionales de la península, en especial Cataluña, Valencia y Murcia (Lenaghan, 2009c: 74). Una situación que viene determinada tanto por el hecho de que cuando esta experta se incorpora a la Hispanic estas secciones de la fototeca ya poseen un significativo volumen (por ejemplo las obras de Laurent), como porque le resultaba más fácil al equipo adquirir imágenes de los realizadores locales (Lenaghan, 2012: 20). Fuera como fuese tal situación, las piezas relacionadas con esta zona española, que aparecen 
en este instante, vienen determinadas por su interés profesional como investigadora de la vestimenta de los pueblos españoles. En este sentido, Anderson en estas fechas ya ha demostrado, sobradamente, sus cualidades como fotógrafa -algo que queda patente desde la primera expedición realizada junto a su padre, Alfred Anderson, a Galicia en 1924 (Lenaghan, 2009a: 15)-. De modo que cuando hay que documentar diferentes matices de la cultura española, en la mencionada Exposición Ibero-Americana, no se duda en mandar a esta autora de forma individual. La Hispanic se interesó por este tipo de eventos porque en ellos era fácil obtener material gráfico de las localidades que se reunían allí, además de que el ejecutante podía fotografiar todo aquello que le atrajera como, por ejemplo, los ambientes de los pabellones decorados con los objetos tradicionales de la zona geográficocultural que representaban. Dentro de este contexto, encontramos veintiuna imágenes que diseccionan con minuciosidad el interior y los elementos que componen una tipología de casa huertana: cocina, tinajas, estanterías, etc.; al tiempo que registran los enseres y las herramientas que caracterizan al hombre rural, sobretodo relacionadas con su trabajo en el campo y con los animales que utiliza para su labranza y transporte. Y, cómo no, sus trajes, las vestimentas características del huertano: elementos autóctonos que son escrupulosamente representados con prominencia de detalles en todas sus texturas y complementos. Así, desde las esparteñas hasta el tocado de la cabeza, todo es fotografiado en diferentes vistas descriptivas, acometiéndose a modo de un estudio científico-documental.

Gráfico 4

FOTOGRAFÍAS RELACIONADAS CON MURCIA EN LA COLECCIÓN DE LA HISPANIC SOCIETY OF AMERICA REALIZADAS POR EL PERSONAL DEL CENTRO, COMPRADAS A FOTÓGRAFOS Y MARCHANTES Y RECIBIDAS A TRAVÉS DE DONACIONES

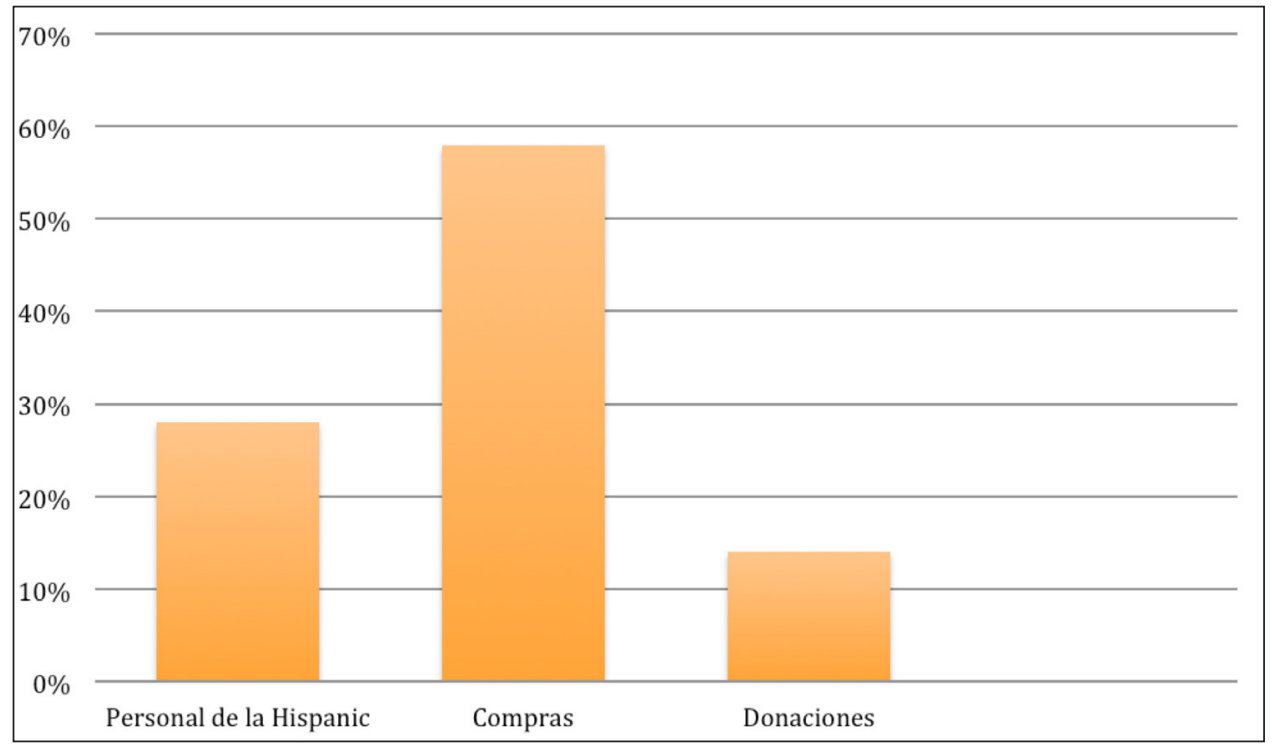


En último lugar, pero no menos importante, situamos el tercer método de ampliación del fondo fotográfico, que, como ya apuntamos, viene determinado por el sistema de la donación. Un procedimiento que, aunque se reduce a un muestrario muy específico, es igualmente significativo, ya que dichas colecciones enriquecen en su conjunto el archivo de la institución. Uno de los casos más destacados es la aportación de Benigno Mariano Pedro Casto de la Vega-Inclán y Flaquer. Aristócrata que mantiene una profunda relación con Huntington; y es que ambos eruditos son amigos y personas afines, conceptualmente hablando, pues perseguían objetivos similares con respecto a la recuperación y puesta en valor del arte español (Lenaghan, 2009b: 214), y opinaban que sus instituciones (sus museos) deben presentarse no como unas simples colecciones de arte, sino como un homenaje al espíritu de una época (Lenaghan, 2014: 173). En este sentido, hay que tener en cuenta que Huntington, a partir de 1882, realiza diferentes viajes a España; en ellos visita distintas localidades del país, entrando en contacto con variados intelectuales y entablando amistad con otros tantos aristócratas españoles, siendo uno de ellos el marqués de la Vega-Inclán. Es este un personaje sensible por el que cultiva un afecto verdadero, basado en la admiración y respeto mutuos, que se cimenta porque ambos, como ya hemos apuntado, pretenden y desean unas mismas metas culturales, lo que tiene como derivación que se apoyen, recíprocamente, en los sucesivos proyectos que los dos afrontan (Lenaghan, 2007a: 58). Así pues, y como reflejo de esa relación y apoyo, en 1934 este intelectual decide depositar, entre otros materiales (ya que también incluye libros y obras de arte), un total de 16. 000 documentos gráficos. El conjunto se compone tanto de fotografías de afamados autores como Garzón, Linares, Moreno o Alguacil, como de obras sin autoría reconocida o, incluso, producidas personalmente por él mismo. Un hecho que se hace posible porque Vega-Inclán, como hombre moderno de su tiempo (en el que encuadramos a eruditos y aristócratas, pero también a otros estamentos de la sociedad), sigue la tradición de finales del XIX y principios del XX de sentirse atraído por coleccionar imágenes y practicar el ejercicio fotográfico (Vega, 2017); y es que él era un aficionado completo, no siendo descabellado que parte de estas escenografías visuales anónimas pudieran haber sido efectuadas por el propio marqués. Sea como fuere, la realidad es que esta acción tiene como consecuencia la incorporación a la colección de la Hispanic de excelentes piezas del siglo XIX y del siglo XX (Lenaghan, 2014: 176).

Dentro de todo este conjunto, específicamente en la sección de imágenes sin autoría y de formato estereoscópico, hallamos un interesante grupo de composiciones relacionadas con la región de Murcia. Un compendio de obras que escudriñan en profundidad la geografía artístico-social de esta tierra. Así, localizamos un total de treinta y siete piezas, en las que se encuentran representadas Murcia, Cartagena y Fortuna. Una gran parte de ellas están dedicadas a la capital, concretamenteveintitrés; repertorio de trabajos que contienen, como esencia y paradigma, aspectos documentales tanto del arte arquitectónico de la localidad como fragmentos de los sucesos sociales y naturales de aquel tiempo. De este modo, el Teatro Romea, con diferentes perspectivas y detalles de sus ruinas, es compuesto como un arquetipode identidad de un lugar; al que siguen ejemplos tan característicos como el puente Viejo o de los Peligros, la estación del tren, el monumento al escultor Francisco Salzillo -en la plaza de San Juan- y la iglesia de San Bartolomé. Unas escenas que se acompañan con vistas tan señeras del municipio 
como el paseo del Malecón, documentos tan personales como los ejercicios fotográficos dedicados alas tradiciones festivas y culturales de esta tierra (por ejemplo su Semana Santa), para cerrar todo este apartado con unos relatos visuales que capturan las catástrofes naturales de la zona: las inundaciones que sufren, con cotidianidad histórica, la ciudad de Murcia y su huerta.

Igualmente interesantes son las diez representaciones que se dedican al núcleo urbano de Cartagena. Como es de esperar, todas ellas depositan su mirada en aquellos rasgos que la identifican y personalizan como localidad. Así, el puerto, como modelo y fisionomía de un lugar, es su principal asunto, dejando testimonio de sus muelles en diferentes vistas generales y fragmentos que abordan, con amplitud, tanto las expresiones relacionadas con lo marítimo como los edificios que desde él se contemplan, teniendo un protagonismo destacado las panorámicas que aluden a la catedral de Santa María. Por último, las cuatro fotografías restantes del conjunto documentan aspectos del municipio de Fortuna, siendo el campo y su balneario los elementos que estas imágenes ponen en valor.

\section{BIBLIOGRAFÍA}

ALMARCHA NÚÑEZ-HERRADOR, E. y LENAGHAN, P. (2012): «Fondos fotográficos en la Hispanic Society of America. La exposición Viaje de Ida y Vuelta», Artigrama, $\mathrm{n}^{\mathrm{o}} 27$, pp. 313-331.

BORROW, G. (1841): The Zincali: or An account of the Gypsies of Spain. London, John Murray.

CAMERON, J. B . (2008): «Léon, Moyse \& Lévy, Isaac; Ferrier, Claude-Marie; and Charles Soulier», en Encyclopedia of Nineteenth-Century Photography, London, Taylor \& Francis Group, vol. I, pp. 850-852.

CODDING, M. A. (2017): «Visiones del mundo hispánico: Archer M. Huntington y la Hispanic Society, Museo y Biblioteca», en Tesoros de la Hispanic Society of America, Madrid, Museo del Prado, pp. 21-37.

DÍAZ FRANCÉS, M. (2016): J. Laurent, 1816-1886: un fotógrafo entre el negocio y el arte. Madrid, Ministerio de Educación, Cultura y Deporte.

ESCOBAR BORREGO, F. J. (2003): «El concepto de intrahistoria como praxis periodística en Andanzas y visiones españolas, de Miguel de Unamuno», Anuario de Estudios Filológicos, no 26, pp. 103-116.

ESPINOSA FERNÁNDEZ, N. (2010): La fotografía en los fondos de la Hispanic Society of America: Ruth Matilda Anderson. Tesis doctoral, Universidad de Castilla-La Mancha.

ESPINOSA FERNÁNDEZ, N. (2016): «Los viajes de estudio y expediciones en la Hispanic Society of America», en El Greco en su IV Centenario: patrimonio hispánico y diálogo intercultural, Cuenca, Ediciones de Castilla-La Mancha, pp. 609-630.

ESPINOSA FERNÁNDEZ, N. (2018): «Hallazgo de lo ignorado: las fotografías de Asturias de Ruth M. Anderson para la Hispanic Society of America», en Hallazgo de lo ignorado: las fotografías de Asturias de Ruth M. Anderson para la Hispanic Society of America, 1925, Oviedo, KRK Ediciones, pp. 13-28. 
FONTANELLA, L. (1981): La historia de la fotografía en España. Desde sus orígenes hasta 1900, Madrid, El Viso.

FONTANELLA, L. y KURTZ, G. (1996): Charles Clifford, fotógrafo de la España de Isabel II. Madrid, El Viso.

FONTENELLA, L. (1999): Clifford en España: un fotógrafo en la Corte de Isabel II. Madrid, El Viso.

FREUND, G. (1999): La fotografía como documento social. Barcelona, Editorial Gustavo Gili.

HIELSCHER, K. (1922): Das unbekannteSpanien. Berlín, E. Wasmuth.

HIELSCHER, K. (2007): La España desconocida. Granada, Edilux.

HUNTINGTON, A. M. (1898): A Note-book in Northern Spain. New York, Putnam.

JIMÉNEZ BLANCO, M. D. y MACK, C. (2010): Buscadores de belleza: historias de los grandes coleccionistas de arte. Madrid, Ariel.

KATZ, I. J. y MANZANO ALONSO, M. (1991): Música y poesía popular de España y Portugal. Salamanca, Diputación Provincial de Salamanca.

LENAGHAN, P. (2003): «La formación del archivo fotográfico de la Hispanic Society of America: un experimento de Archer Milton Huntington y Ruth Matilda Anderson», en Salamanca en los fondos fotográficos de la Hispanic Society of America, Salamanca, Junta de Castilla y León, Consejería de Educación y Cultura, pp. 17-33.

LENAGHAN, P. (2004): «En tierras de Extremadura», en En tierras de Extremadura: las fotografías de Ruth Matilda Anderson para la Hispanic Society, Badajoz, The Hispanic Society of America y Museo Extremeño e Iberoamericano de Arte Contemporáneo, pp. 11-91.

LENAGHAN, P. (2007a): «La visión de Archer M. Huntington y las fotografías de Castilla-La Mancha en The Hispanic Society», en Viaje de ida y vuelta, Toledo, Empresa pública Don Quijote de la Mancha S.A pp. 56-67.

LENAGHAN, P. (2007b): «La formación de una colección fotográfica de Castilla-La Mancha: monumentos, tipos y trajes», en Fotografía y Patrimonio. II Encuentro en CastillaLa Mancha, Ciudad Real, Centro de Estudios de Castilla-La Mancha, pp. 64-80.

LENAGHAN, P. (2009a): «Haciendo la Crónica de Galicia», en Una mirada de antaño. Fotografías de Ruth Matilda Anderson en Galicia, La Coruña, Fundación Caixa Galicia y Hispanic Society of America, pp. 15-43.

LENAGHAN, P. (2009b): «Archer M. Huntington y las fotografías sobre arqueología española», en El tesoro arqueológico de la Hispanic Society of America, Madrid, Museo Arqueológico Regional, pp. 213-227.

LENAGHAN, P. (2009c): «Documentos en color: las placas autocromas de Anderson para la Hispanic Society of America», en El color del Sol: la placa autocroma en España, Madrid, El Viso, pp. 69-87.

LENAGHAN, P. (2012): «En busca de la España castiza: el hispanista y la fotografía», en Atesorar España. Fondos fotográficos de la Hispanic Society of America, Valencia, Fundación Bancaja, pp. 17-22.

LENAGHAN, P. (2014): «Mis felicitaciones más efusivas por su plan», en Visite España: la memoria rescatada, Madrid, Ministerio de Cultura, pp. 161-179. 
LENAGHAN, P. (2017a): «Un retrato de España: Huntington, Sorolla y Zuloaga en la Hispanic Society of America», en Tesoros de la Hispanic Society of America, Madrid, Museo del Prado, pp. 61-83.

LENAGHAN, P. (2017b): «Una Kodak para el viaje al Sur: Archer M. Huntington y la Colección de Fotografías de Latinoamérica de la Hispanic Society», en Visiones de Latinoamérica en la Hispanic Society of America. Vistas Urbanas, Madrid, El Viso, pp. 9-19.

LENAGHAN, P. (2018a): «From Andalucía to Vizcaya: "Recuerdos y bellezas" of an unknown Alguacil», en Fotografía y patrimonio cultural V, VI y VII. Encuentros en Castilla-La Mancha, Cuenca, Ediciones de la Universidad de Castilla-La Mancha y Centro de Estudios de Castilla-La Mancha, pp. 191-208.

LENAGHAN, P. (2018b): «El álbum del ferrocarril: los magnates y sus fotógrafos», en Visiones de Latinoamérica en la Hispanic Society of America . La industria, Madrid, El Viso, pp. 39-49.

LENAGHAN, P. y GARCÍA DE CORTÁZAR, F. (2007): Álbum de Andalucía y Murcia. Viaje de S. M. la reina Isabel II de Borbón y la Familia Real en 1862. Charles Clifford. Sevilla, Fundación Lara.

LÓPEZ MONDÉJAR, P. (2005): Historia de la fotografía en España. Fotografía y sociedad desde sus orígenes al siglo XXI. Barcelona, Lunwerg.

MCCAUlEY, E. A. (1994): Industrial Madness. Commercial Photographs in Paris. 1848-1871. New Haven, Yale University Press.

MERINO DE CÁCERES, J. M. (2011): «Arthur Byne, un expoliador de guante blanco», en La dispersión de objetos de arte fuera de España en los siglos XIX y XX, Barcelona, Universitat de Barcelona, pp. 240-272.

PÉREZ MATEO, S. (2018): «Vega Inclán y las Casas Museo: un concepto inédito del turismo cultural en la España de Alfonso XIII», Cuadernos de Turismo, nº 42, pp. 421-445.

SCHUBERT, O. (1908): Geschichte des Barock in Spanien. Esslingen, Paul Neff Verlag (Max Schreiber).

TEIXIDOR CÁRDENAS, C. (2003): «Los fotógrafos de la casa Laurent, en tierras valencianas (1858-1870)», en Las fotografías valencianas de J. Laurent, Valencia, Ajuntament de Valencia, pp. 29-36.

VÁZQUEZ CASILLAS, J. F. (2008): «Murcia: miradas fotográficas», en Murcia y Cartagena en las fotografías de Laurent y Loty, 1871 y 1930, Madrid, Fundación Mapfre, pp. 24-37.

VEGA, C. (2008-2009): «Fotografía y turismo en España. Políticas para una imagen de la diferencia», Estudis Balearics, n 94-95, pp. 193-206.

VEGA, C. (2011): Lógicas turísticas de la fotografía. Madrid, Cátedra.

VOIGNIER, J. M. (1992): Les vuesstéréoscopiques de Ferrier et Soulier. París, Edition du Palmier en Zinc. 